Primljeno: 12. 7. 2020.

Prihvaćeno za štampu: 9. 11. 2020.

\author{
Dr. sc. Hakija Kanurić, docent \\ Univerzitet u Bihaću \\ Islamski pedagoški fakultet \\ E-mail: bakijak@hotmail.com
}

\title{
MREŽNI MARKETING S ASPEKTA ISLAMSKOG PRAVA
}

\section{Sažetak}

Ovaj rad ima za cilj predstaviti mrežni marketing kao model poslovanja, distribucije $i$ prodaje robe, ukazati na njegove pozitivnosti i negativnosti, prakticna iskustva $i$ zakonske regulative nekih zemalja spram ovog poslovnog modela, te elaborirati mišljenja savremenih islamskih pravnika o mrežnom marketingu $i$ na koncu eksplicirati njegov šerijatsko-pravni status te objasniti da li je kompatibilan islamskim normama poslovanja ili ne.

Prilikom proučavanja i analiziranja mre⿻̌nog marketinga korištena je metoda teorijske analize, deskriptivno-analiticke a $i$ komparativna metoda.

Rezultat studije pokazuje da je mrę̌ni marketing u svojoj nobičajenoj formi, pri kojoj se članstvo uvjetuje novčanom uplatom ili kupovinom proizvoda, zabranjen. Da bi mrežni marketing s aspekta islamskog prava bio pribvatliv, neophodno je da prodaja tim putem zadovoljava opíe uvjete kupoprodaje u islamskom pravu, da proizvod koji se tim putem prodaje vrijedi cijene koja se za njega plaća, da se kroz. marketing proizvoda ne služi obmanom $i$ da se ne uzima profit od clanova iz nižih nivoa kojima se ne rini nikakva usluga.

Ključne riječi: mre⿻̌ni marketing, MLM (multi-level marketing), model poslovanja, distribucija i prodaja robe, finansijjka piramida, islamsko pravo. 


\section{Uvod}

U posljednje vrijeme učestala su pitanja o mrežnom marketingu - da li je s aspekta islamskog prava dozvoljen ili ne. Prvi korak ka odgovoru na ovo pitanje jeste dobiti jasnu i potpunu sliku o tom poslovnom modelu. Potom slijedi analiza mrežnog marketinga kroz prizmu načela islamskog poslovanja, prezentiranje mišljenja islamskih pravnika o ovom novitetu, argumenata na koja se pozivaju i na koncu zaključak i ekspliciranje odabranog mišljenja.

\section{Suština i način funkcioniranja mrežnog marketinga}

Mrežni marketing se još naziva i višerazinski marketing (eng. multilevel marketing, skr. MLM). Prvobitno je nastao u SAD-u ${ }^{1}$, a potom se postepeno razvijao i širio diljem svijeta.

Mrežni marketing je distribucija i prodaja proizvoda i usluga izravno potrošačima na temelju individualnih kontakata, obično kod kuće klijenata, na radnom mjestu ili na drugim mjestima izvan stalnih poslovnica s maloprodajnim mjestom. ${ }^{2}$ Time se kupoprodaja često odvija među poznanicima što kupcima daje dodatno pouzdanje.

Kupovinom startnog paketa postaje se distributer/član MLM poduzeća i dobiva se distributerski račun. Članovi MLM poduzeća mogu zaraditi novac na dva načina:

Prvi je direktnom prodajom proizvoda, jer svaki novi distributer kupuje robu po nižim cijenama i ostvaruje zaradu na razlici između nabavne $\mathrm{i}$ prodajne cijene.

Drugi način odnosi se na zapošljavanje novih članova. Članovi MLM poduzeća mogu regrutirati ljude kao nove distributere, da prezentiraju, reklamiraju i prodaju proizvode svojim klijentima. Na taj način svaki

\footnotetext{
${ }^{1}$ Početak prvog MLM modela vezuje se za 1934. godinu, kada je Carl Rehnborg osnovao California Vitamin Corporation koja je proizvodila i prodavala dodatke prehrani. Vidjeti: http://rajnabanovac.com/2016/10/21/povijest-mlm-a/ pristup: 24. 6 . 2020.

2 Vidjeti: Alvađ Saša, Mrežni marketing na primjeru poduzeća Amway, 4, Studij Poslovna ekonomija, Varaždin. https://repozitorij.unin.hr/islandora/object/unin\%3A1910/datastream/PDF/view, pristup: 25.1 .2020$.
} 
član MLM poduzeća ima priliku izgraditi vlastitu strukturu saradnika kojima on postaje mentor, biva im na usluzi i pomaže u biznisu. Proporcionalno razvoju mreže i aktivnosti njenih članova, dobivaju se bonusi, rangovi i činovi, a time raste i dobit. Bonus sistem u mrežnom marketingu omogućava generiranje pasivnog dohotka, odnosno, prihoda koji nije izravni učinak dijela prodaje. Ovakav sistem omogućava aktivnim saradnicima koji dovode nove članove da ostvare velike zarade, a ko nije u stanju dovoditi nove članove neće napredovati. ${ }^{3}$

Ovo su osnovna obilježja mrežnog marketinga, a unutar njega postoje različiti modeli i planovi naknada, kao što je binarni plan, plan matrice, linearni plan i sl. ${ }^{4}$

\section{Mrežni marketing i finansijska piramida}

Finansijska piramida je poslovni model za čije je pokretanje i funkcioniranje potrebno uključivati sve veći broj sudionika koji su spremni uplatiti određeni iznos novca. Dobici za neke članove nastaju, ako pronađu nove sudionike koji su spremni uključiti se i uložiti novac. U većini zemalja ovakvi modeli poslovanja zakonski su zabranjeni. ${ }^{5}$

Ilegalna finansijska piramida ne nudi proizvod s realnom vrijednošću, a djeluje na principu plaćanja za zapošljavanje. Iako se može ponuditi neka vrsta proizvoda ili usluga, to obično služi samo kao mamac, jer ovo nije stvarno vrijedan proizvod, ne vrijedi novca koji se plaća. ${ }^{6}$ Dakle, piramida model ne podrazumijeva nužno odsustvo proizvoda koji se prodaje, ali je primarni akcent na učlanjivanju novih članova. Zbog toga se ovaj sistem i naziva piramida jer se novi članovi dodaju u nivo ispod onih starijih, što će formirati piramidu. Na vrhu piramide je njen utemeljitelj, a na dnu su članovi koji su posljednji pristupili tom sistemu. $^{7}$

\footnotetext{
${ }^{3}$ Ibid, 3-8.

${ }^{4}$ Ibid, 15-31.

${ }^{5}$ Vidjeti: https://hr.wikipedia.org/wiki/Piramida_sreće, pristup: 25. 1. 2020.

${ }^{6}$ Vidjeti: Alvađ Saša, Mrežni marketing na primjeru poduzeća Amway, 13.

7 Džasim el-Harun, Šerikatul-ihtijali et-tesvik ě̌-šebeki, https://goo.gl/zqpDbx, pristup: 25. 1. 2020.
} 
MLM poduzeće prodaje vrijedan proizvod za razliku od ilegalne piramide koja prodaje ,maglu“, tj. prodaje priču o brzoj zaradi kako bi privukli ljude, a onda ljudi da bi ušli u ilegalnu piramidu moraju platiti određeni iznos. U mrežnom marketingu prodaja se temelji na proizvodu ili usluzi, a provizijski sistem nagrađuje sudionike ovisno o njihovom doprinosu, bez obzira na položaj na kojem se nalaze. ${ }^{8}$ Prema tome, ključna razlika između MLM-a i ilegalne piramide bila bi da MLM pokreće vrijedan proizvod koji se prodaje širokim masama, a sve isplate se vrše za prodaju tog proizvoda ili usluge, a ne za zapošljavanje. ${ }^{9}$

Mrežni marketing, koji se bazira na prodaji kvalitetne robe, načelno je naišao na prijem u Evropi i Americi, a potom se, nakon što su ga podržali neki ekonomski eksperti, raširio i u drugim zemljama. Ipak, u praksi se dešava pretvaranje mrežnog marketinga u ilegalnu piramidu. Zbog toga su neke zemlje potpuno zabranile mrežni marketing, a neke su ga dozvolile uz striktne uvjete koji sprečavaju da se mrežni marketing pretvori u ilegalnu piramidu. Tako je, naprimjer, Vlada Kanade dozvolila mrežni marketing ukoliko se ispune sljedeći uvjeti:

1. Da se članovima ne uvjetuje novčani ulog u zamjenu za naknadu koju ostvaruju uvjeravanjem drugih da se pridruže sistemu.

2. Da se članovima ne uvjetuje kupovina određene količine proizvoda po cijeni većoj od stvarne cijene.

3. Da član ima mogućnost povrata proizvoda kompaniji prema ustaljenim uvjetima tržišta. ${ }^{10}$

Kina je još 1998 . u potpunosti zabranila mrežni marketing. ${ }^{11}$ Neke arapske zemlje također su potpuno zabranile mrežni marketing kao i ilegalnu piramidu. Među tim zemljama su Saudijska Arabija i Bahrejn, a Sirija je zabranila djelovanje kompanije koja je radila po modelu mrežnog marketinga zbog prevara i obmana u radu. ${ }^{12}$

\footnotetext{
${ }^{8}$ Debra A. Valentine, Pyramid Schemes, goo.gl/mrTEk3, pristup: 26. 1. 2020.

${ }^{9}$ Alvađ Saša, Mrežni marketing na primjeru poduzeća Amway, 10-14.

${ }^{10}$ Vidjeti: http://laws-lois.justice.gc.ca/fra/lois/C-34, pristup: 26. 1. 2020.

${ }^{11} \mathrm{https}$ //en.wikipedia.org/wiki/Multi-level_marketing, pristup: 26. 1. 2020.

12 Vidjeti: Hamza Adnan Mešuka i Ahmed Nuajm Husejn, Et-Tesvik ě̌-šebekijj min menzurin iktisadijjin islamijj, 18-23.
} 
$\mathrm{Na}$ internet-portalima možemo naći brojna individualna iskustva sa MLM poduzećima koja pravdaju restriktivne mjere kakve su ove vlade poduzele. $^{13}$

Kao primjer transformacije mrežnog marketinga $u$ ilegalnu piramidu navodimo i rezultat istraživanja koje je sproveo student Sveučilišnog centra Varaždin, na primjeru poduzeća Amway. U zaključku rada između ostalog navodi: „Ilegalna piramida obično ne nudi nikakav proizvod s bilo kakvom realnom vrijednošću, a djeluje na principu

${ }^{13}$ Ilustracije radi navest ćemo jedno takvo iskustvo koje ističe da o MLM poduzećima postoje četiri velike zablude, a to su:

„Prvo: Tvrdnja da je mrežni marketing posao koji vas ne košta ništa, osim učlanjenja ili početnog paketa. Istina je da postoji čitav niz ulaganja, koja će vaš ulazak u jedan MLM sistem pretvoriti u vrlo skupu zabavu, a koju vam, ni u kom slučaju, neće na početku pomenuti. Ubijedit će vas da morate isprobati sve (ili bar većinu) proizvoda dotične firme kako biste ih mogli uspješno preporučivati drugim. Zatim, postoji čitav niz priručnika, koje morate nabaviti ako želite da budete uspješni. Uz njih obično idu promo-materijali koji dotičnu kompaniju prikazuju u najboljem svjetlu, a za to su potrebna ulaganja. Tu su i različiti seminari za obuku, koje, naravno, plaćate iz svog džepa. Zatim, motivacioni sastanci, večere i druženja, telefonski računi, troškovi puta jer odjednom krenete da obilazite rodbinu i prijatelje u bližim i daljim mjestima, a sve su to ulaganja.

Drugo: Tvrdnja da mrežni marketing nije piramida. Međutim, stvarnost je da MLM jeste piramidalna struktura na čijem se vrhu nalazi firma ili kompanija, koja, jedina, ima zaista veliku zaradu od ovog sistema. Odmah ispod nje je par desetina ili stotina najuspješnijih, koji su prvi počeli u različitim zemljama. Oni, najčešće, nose zvučne titule kao što su: dijamanti, brilijanti i ini, što asocira na raskoš i bogatstvo ili su izvršni ili nekakvi drugi direktori, što asocira na moć i bogatstvo.

Treće: Tvrdnja da je spisak rođaka i prijatelja vaš jedino potrebni kapital. Međutim, vaše tržište se brzo zasiti, a vi se, polako ali sigurno pretvarate u akvizitera koji prodaje od vrata do vrata, putem oglasa, preko interneta, ili "davite" svoje rođake $\mathrm{i}$ prijatelje, toliko da oni počinju da prelaze na drugu stranu ulice kad vas vide iz daljine...

Četvrto: Tvrdnja da je mrežni marketing posao kojim svako može da se bavi i da u njemu uspije. Ako ste, odavno prestali da vjerujete u bajke bit će vam jasno da je ovo istina taman toliko koliko i tvrdnja da svaka djevojka može postati Pepeljuga, Trnoružica ili neka slična princeza..." https://mlmprevara.wordpress.com /2014/02/24/5-velikih-lazi-mreznog-marketinga, pristup: 26. 1. 2020. 
plaćanja za zapošljavanje... Po tome bi zaključili da su Avon, Amway, Tuperware, Zepter i ostali ilegalne piramide.“"14

\section{Refleksije mrežnog marketinga na ekonomiju}

Ekonomisti koji podržavaju mrežni marketing ističu neke njegove prednosti i pozitivnosti od kojih su: niski početni troškovi, niski troškovi distribucije s obzirom na to da ovaj model zaobilazi brojne posrednike između proizvođača i krajnjih korisnika, dolazi s velikom radnom snagom koja raste vrlo brzo, dobro je sredstvo za dodatnu zaradu i jednostavan model za pokretanje vlastitog biznisa. ${ }^{15}$

S druge strane ekonomisti koji se protive mrežnom marketingu ističu njegove negativnosti, od kojih su:

Prvo: Ne zadovoljava potrebe savremenog tržišta i nije kompatibilan tehnološkim ostvarenjima današnjice. Naime, mrežni marketing nastao je i razvio se u Americi u vremenu koje je prethodilo epohi interneta, brze i lahke komunikacije i razmjene informacija. $\mathrm{U}$ tom vremenu bilo je teško dostaviti informacije krajnjim korisnicima u udaljenim krajevima i predstaviti im proizvod koji im može olakšati život, ili poboljšati proizvodnju i donijeti velike koristi. Dok danas, proizvođač lako može predstaviti svoje proizvode i najudaljenijim kupcima, a kupac može s lahkoćom naručiti proizvod od proizvođača na drugom kraju svijeta, i proizvod će mu stići u relativno kratkom roku. To znači da potreba za mrežnim marketingom nije kao što je nakad bila. ${ }^{16}$

Individualna prodaja prevaziđena je i predstavlja prošlost, a ne budućnost. Izravnom prodajom poznanicima i prijateljima navode se kupci da mijenjaju svoje kupovne navike i standarde, u ovom modelu izbor robe je ograničen i ne liči izboru u tržnim centrima, a proizvodi koji se tim putem prodaju prelaze realnu cijenu čak i ako su visoko kvalitetni. ${ }^{17}$

\footnotetext{
${ }^{14}$ Alvađ Saša, Mrežni marketing na primjeru poduzeća Amway, str. 49.

15 Ibid.

16 Džasim el-Harun, Šerikatul-ihtijali et-tesvik ěs-šebeki, https://goo.gl/zqpDbx, pristup: 25. 1. 2020.

17 Robert FitzPatrick, Ekberu ašereti ekazib anit-tesvik ě́-šebeki, https://goo.gl/AiT82W.
} 
Drugo: Mrežni marketing marginalizira primarnu ulogu marketinga, odnosno prodaju robe i usluga krajnjim korisnicima. Jedna od najvećih kompanija mrežnog marketinga priznaje da obim njene prodaje kupcima, koji nisu njihovi članovi ili ne žele graditi vlastitu prodajnu mrežu, ne prelazi $18 \%{ }^{18}$

Treće: Obmana je prisutna i ustaljena u svim sistemima mrežnog marketinga. Većina onih koji su investirali u mrežni marketing na koncu otkriju da su gubitnici u tom poslu i to je potvrđena historijska činjenica.

Analizom reklamnih podataka više od 40 kompanija koje se bave prodajom ljekovitih preparata putem mrežnog marketinga u Americi, ustanovljeno je da se u svim tim reklamnim informacijama mnogo pretjeruje. ${ }^{19}$ Poslovanje modelom mrežnog marketinga ne podliježe finansijskim inspekcijama i izvan je kontrole i kvalitetnoga nadzora, a to je jedan od temeljnih agensa rasprostranjenosti obmane i prevare. ${ }^{20}$

\section{Mišljenja islamskih učenjaka o mrežnom marketingu}

Prije govora o različitim mišljenjima učenjaka po ovom pitanju potrebno je ukazati na tačke po kojima su složni, locirati tačku razilaženja i precizirati formu poslovanja o kojoj su učenjaci zauzeli različite stavove.

Savremeni učenjaci načelno ne osporavaju mrežni marketing ukoliko se ispune dva uvjeta:

Prvi se odnosi na temelj ovog poslovnog modela, a to je uvjetovanje članarine ili kupovine u zamjenu za marketinški poticaj. Ukoliko bi se članstvo u mrežnom marketingu ostvarivalo bez uplate članarine ili kupovine početnog paketa, članovi MLM poduzeća ili distributeri bili bi zastupnici vlasnika robe i uzimali proviziju za svoj uspješan

\footnotetext{
18 Ibid.

${ }^{19}$ Analizu je sproveo Stephen Barrett predsjednik Izvršnog odbora Nacionalnog vijeća za suzbijanje prevara na polju zdravstva. Vidjeti: Muhammed Emin, Gasilul-emvali tahte sitarit-tesvikiš-šebeki, www.masress.com/october/124297, pristup: 27. 1. 2020. ${ }^{20}$ Vidjeti: Hamza Adnan Mešuka i Ahmed Nuajm Husejn, Et-Tesvik ěs-šebekijj min menzurin iktisadijjin islamijj, 7-9.
} 
marketing. To je posredovanje u kupoprodaji putem kojeg se legalno uzima naknada i ostvaruje profit.

Drugi uvjet je da predmet prodaje bude dozvoljen s aspekta šerijata i da se ispune opći uvjeti kupoprodaje.

Islamski učenjaci podijeljeni su po pitanju šerijatsko-pravnog statusa mrežnog marketinga u svojoj uobičajenoj formi, pri kojoj se članstvo uvjetuje novčanom uplatom ili kupovinom proizvoda, na dva mišljenja: ${ }^{21}$

Prvo mišljenje: Većina savremenih učenjaka zabranila je mrežni marketing. Brojni kolegiji islamskog prava izdali su fetve o zabrani, a među njima je Stalna komisija za fetve u Saudijskoj Arabiji, Kolegij islamskog prava u Sudanu, Akademija za fetve u Jordanu, Centar za fetve u Egiptu i Centar za fetve u Palestini. Isto tako, brojni učenjaci koji su individualno istraživali ovo pitanje zaključili su da mrežni marketing nije dozvoljen, od kojih su: dr. Sami es-Suvejlim, dr. Ibrahim ed-Darir, dr. Ali es-Salus, dr. Ahmed el-Hadži el-Kurdi, dr. Jusuf ešŠubejli, dr. Husejn Šsehate i drugi. ${ }^{22}$

Drugo mišljenje: Dio savremenih učenjaka stanovišta je da je mrežni marketing dozvoljen. To je stav Centra za fetve u Libiji, Tunisu i Egiptu, kao i Komisije za fetve pri Ezheru. ${ }^{23}$ Stav da je mrežni marketing dozvoljen zastupa i dr. Salih es-Sedlan, šejh Ahmed elHaddad, dr. Vedžih Abdulkadir eš-Šejmi, i drugi. ${ }^{24}$ Šejh Selman elAude uslovno je dozvolio mrežni marketing ističući da takav model poslovanja može biti dozvoljen samo ako je izgrađen s ciljem da

\footnotetext{
${ }^{21}$ Vidjeti: Belfekih Zahir Salim, Et-Tesvik eš-šebekijj tahtel-midžher, str. 13. https://www.noor-book.com/كتاب-التسويق-الشبكي-تحت-المجهر-pdf, Pristup: 10. 2. 2020.

22 Vidjeti: Fetva Stalne komisije br. 22935, Fetva Kolegija islamskog prava u Sudanu, izdata 28. 1. 1429. h. g. Belfekih, Et-Tesvik eš-šebekijj tahtel-midžher, str. 14, Hamza Adnan Mešuka i Ahmed Nuajm Husejn, Et-Tesvik eš-šebekijj mim menzurin iktisadijjin islamijj, str. 11, https://www.aliftaa.jo/Research.aspx?ResearchId=102\#.XkFMfX_PyUk.

23 Neke od ovih institucija zabranile su mrežni marketing nakon što su ga bile dozvolile. Vidjeti: https://goo.gl/78jn8Z.

24 Vidjeti: Belfekih, Et-Tesvik eš-šebekijj tahtel-midžher, str. 14, Hamza Adnan Mešuka i Ahmed Nuajm Husejn, Et-Tesvik eš-šebekijj mim menzurin iktisadijjin islamijj, 10, https://goo.gl/O4WAUa.
} 
prodaje vrijednu i kvalitetnu robu. Međutim, ako je roba samo zastor, a cilj je profitirati putem mrežne strukture, onda je to zabranjeno. ${ }^{25}$

\section{Argumenti zabrane mrežnog marketinga i odgovori na njih}

Prvo: Mrežni marketing involvira kocku i hazard, a to je šerijatom zabranjeno. $^{26}$

Ovaj dokaz bazira se na tome da roba koja se prodaje modelom mrežnog marketinga nije primarno ciljana, nego član mrežnog marketinga kupuje robu da bi ostvario provizije koje mu MLM poduzeće nudi. Na takav način roba gubi svoj kupoprodajni smisao i dobiva se sljedeća forma: član MLM poduzeća plaća novac kako bi dobio očekivani iznos, a realizacija tog iznosa je neizvjesna. To je bit kocke, s obzirom na to da član koji je uložio novac ne može pouzdano znati da će naći nove članove koji će kupovati putem njega. To je naročito izraženo u nižim nivoima mreže. Interesantno je da identičan pogled na mrežni marketing dijele pojedini ekonomski eksperti sa Zapada, štaviše, neke studije su pokazale da je prosjek gubitka u mrežnom marketingu veći od gubitka na kocki. ${ }^{27}$

Drugi dokaz: Ova poslovna relacija sadrži kamatu, s obzirom na to da agent mrežnog marketinga uplaćuje novac da bi kasnije dobio veći iznos novca. Dakle, radi se o razmjeni novca za novac uz odgodu i razliku u vrijednosti, a to je suština kamate. Roba koju MLM poduzeće prodaje svojim partnerima samo je formalno sredstvo kojim se prikriva ova razmjena, tako da ne utječe na status ove transakcije.

\footnotetext{
${ }^{25}$ Rekao je: ,Težim ka tome da se sud o ovom i njemu sličnim pitanjima treba graditi na suštini i realnom stanju. Ako su usluge koje MLM poduzeće nudi vrijedne i prepoznatljive kvalitetom ili povoljnom cijenom, na tome se gradi partnerstvo, a osnovni motiv pridruživanja MLM poduzeću je iskoristiti njegove proizvode i usluge i nuditi ih drugima, to je onda dozvoljeno. Mnogi saradnici jedne takve kompanije su mi to i potvrdili. Međutim, ako su usluge, programi ili roba u tom sistemu samo zastor, ili su slabe, lošeg kvaliteta i nemaju realne vrijednosti, nego se članovi pridružuju tom sistemu i promoviraju njegove proizvode i usluge kako bi ostvarili materijalnu dobit koja ih čeka kada uspiju nagovoriti druge ljude da im se pridruže, onda je to zabranjeno, a Allah najbolje zna.“ https://goo.gl/xL7PvP.

${ }^{26}$ Vidjeti: Belfekih, Et-Tesvik eš-šebekijj tahtel-midžher, str. 15.

${ }^{27}$ Radi se o studiji koju je sproveo dr. John Taylor. Vidjeti: https://goo.gl/bEBZdm.
} 
Treći dokaz: Putem mrežnog marketinga bespravno se uzima tuđi imetak. Vlasnici kompanije i establišment na vrhu piramide enormno profitiraju na račun nižih nivoa, dok široki temelj piramide ostaje bez zarade usljed zasićenja tržišta i nedostatka novih članova. Bespravno uzimanje tuđeg imetka također je evidentno kada saradnik ne uspije ispuniti potrebne uvjete za postizanje bonusa, a ostvario je neke interese poduzeća, pritom je uzaludno utrošio vrijeme, trud, troškove prijevoza i sl., a zauzvrat neće dobiti ništa, iako je kompanija od njega imala koristi.

Četvrti dokaz: Mrežni marketing krije prevaru i obmanu u samom ugovoru ili u proizvodima koje prodaje i to:

- predstavljanjem da je cilj ovog poslovnog modela prodaja proizvoda, a stvarnost je suprotna tome, jer je stvarni cilj profit putem mrežne strukture;

- davanjem obećanja kupcima da će lahko i brzo profitirati ako se pridruže tom sistemu, a to se u stvarnosti vrlo rijetko dešava;

- preuveličavanjem koristi i kvaliteta proizvoda koje prodaju. ${ }^{28}$

Protagonisti drugog mišljenja odgovorili su na ove dokaze kazavši da kupovina robe koja ima vrijednost anulira mogućnost poistovjećivanja ovog poslovnog modela s kockom, jer član mrežnog marketinga svojim novcem kupuje vrijednu robu poznatih svojstava. Isto tako, postojanje vrijedne robe pokazatelj je da se istinski želi kupoprodaja, a ne kamata, jer se ne daje novac za novac. Također u ovom poslovnom modelu nema prevare s obzirom na to da se kupuje roba koja je definirana, poznatih specifikacija, korisna i upotrebljiva. Također, tu ne postoji neizvjesnost ili prevara, štaviše, neke kompanije daju mogućnost da se roba vrati nakon što se proba, ukoliko kupac ustanovi da roba nije kao što je opisana. A to što neki članovi neće profitirati, kompanija im to nije ni obećala, nego je dala mogućnost marketinga i obznanila kako se

\footnotetext{
28 Vidjeti: Belfekih, Et-Tesvik ěs-šebekijj tahtel-midžher, str. 15-16, Hamza Adnan Mešuka i Ahmed Nuajm Husejn, Et-Tesvik eš-šebekijj mim menzurin iktisadijjin islamijj, str. 11-13.
} 
profit ostvaruje, a uvjeti u ugovorima su validni, osim ako bi zabranjivali dozvoljeno ili dozvoljavali zabranjeno. ${ }^{29}$

\section{Argumenti dozvole mrežnog marketinga i odgovori na njih}

Prvi dokaz: Svevišnji Allah dozvolio je kupoprodaju, a osnova je da je svaki vid kupoprodaje dozvoljen sve dok se ne uspostavi dokaz da je zabranjen, pa je tako i mrežni marketing dozvoljen. ${ }^{30}$

Ovom argumentu oponiraju prethodni dokazi koji ukazuju da u ovom poslovnom modelu postoje šerijatom zabranjene stvari. Sporna tačka u ovom pitanju i jeste da li postoje dokazi zabrane, jer protagonisti prvog stava prihvataju da je osnova u poslovanju dozvola sve dok se ne dokaže zabrana, ali je zabrana ovdje višestruko potvrđena. ${ }^{31}$

Drugi argument: Mrežni marketing je vid posredovanja između kupca i prodavca, a naknada koju kompanija daje svojim članovima je nasuprot iznalaženja kupaca i stimulacije prodaje, kao što je običaj prilikom prodaje nekretnina da posrednik uzima procent u cijeni kao naknadu za svoj trud. ${ }^{32}$

Ovom argumentu oponira to što postoji razlika između uzimanja procenta pri prodaji nekretnina i mrežnog marketinga zbog koje se ne mogu poistovjetiti. Naime, prilikom prodaje nekretnina posredniku se ne uvjetuje kupovina predmeta prodaje ili njegovog dijela, niti bilo kakva uplata, za razliku od MLM poduzeća koja to uvjetuju. Posrednik pri prodaji nekretnina ostvaruje pravo na naknadu za svaku prodaju

29 Vidjeti: Redu Risaletil-ustaz Ibrahim el-Kulsum alad-duktur Sami es-Suvejlim, https://goo.gl/xL7PvP, Hamza Adnan Mešuka i Ahmed Nuajm Husejn, Et-Tesvik eššebekijj mim menzurin iktisadijjin islamijj, str. 12.

30 Vidjeti: Belfekih, Et-Tesvik eš-šebekijj tahtel-midžher, str. 16-17, Hamza Adnan Mešuka i Ahmed Nuajm Husejn, Et-Tesvik eš-šebekijj mim menzurin iktisadijjin islamijj, str. 10 .

31 Ibid.

32 Vidjeti: Belfekih, Et-Tesvik eš-šebekijj tahtel-midžher, str. 17, Hamza Adnan Mešuka i Ahmed Nuajm Husejn, Et-Tesvik eš-šebekijj mim menzurin iktisadijjin islamijj, str. 10 . 
koju ostvari dok u MLM poduzeću naknadu ostvaruje samo ako ispuni posebne uvjete. ${ }^{33}$

Treći dokaz: Naknada koju partner u MLM kompaniji ostvaruje putem učlanjivanja novih članova može se poistovjetiti sa tzv. Džialom, a to je dozvoljen ugovor. Džiala je nagrada koja se obećava onom ko uradi neki posao ${ }^{34}$, kao, naprimjer, kada bi rekao: „Ko pronađe moj ukradeni auto dobit će $1000 \mathrm{KM}$." To je dozvoljeno, i na takav način MLM poduzeće nudi nagradu svom distributeru ukoliko ostvari određene rezultate. $^{35}$

Ovom argumentu oponira postojanje razlike između Džiale i MLM modula, s obzirom na to da se pri Džiali ne uvjetuje nikakav materijalni ulog za razliku od MLM poduzeća. Također, prema većini učenjaka, kada radnik obavi dio posla na način da darivalac nagrade time ostvari korist, njemu pripada dio nagrade, dok se u MLM sistemu dešava da partner koristi poduzeću a za to ne bude nagrađen. ${ }^{36}$

Četvrti argument: Mrežni marketing zasnovan je na principu zastupništva uz naknadu, na način da MLM poduzeće sklapa sa svojim partnerom ugovor o marketingu njenih proizvoda, te na osnovu svog truda partner dobiva određenu naknadu. ${ }^{37}$

Ovom, kao i prethodnim argumentima, oponira postojanje bitne razlike između zastupništva uz naknadu i mrežnog marketinga. Razlika se ogleda u tome što se pri ugovoru o zastupništvu ne daje nikakav ulog da bi postao zastupnik, dok u MLM poduzeću partner kupovinom

${ }^{33}$ Ibid.

${ }^{34} \mathrm{U}$ jednoj definicija Džiale navodi se da je to ugovor kojim se imenuje i definira naknada onom ko obavi određen posao, bio taj posao poznat ili nepoznat zbog nemogućnosti da se precizno definira. Vidjeti: El-Mevsuatul-fikhijjetul-kuvejtijje, $15 / 208$.

${ }^{35}$ Vidjeti: Belfekih, Et-Tesvik eš-šebekijj tahtel-midžher, str. 18, Hamza Adnan Mešuka i Ahmed Nuajm Husejn, Et-Tesvik eš-šebekijj mim menzurin iktisadijjin islamijj, str. 10.

${ }^{36}$ Ibid.

${ }^{37}$ Ibid. 
startnog paketa plaća da bi postao zastupnik. Zbog te razlike mrežni marketing se ne može poistovjetiti sa ovim ugovorima. ${ }^{38}$

\section{Zaključna razmatranja}

Problematika mrežnog marketinga bazira se na uvjetovanju kupovine startnog paketa ili novčane uplate. Kada bi se partnerstvo u mrežnom marketingu ostvarivalo bez uplate ili uvjetovanja kupovine određenih proizvoda, partner bi uzimao naknadu po principu zastupništva ili naknade za učinak u marketingu, a to je legitimno i dozvoljeno.

$\mathrm{S}$ obzirom na to da se partnerstvo u mrežnom marketingu uvjetuje kupovinom startnog paketa ili uplatom velika većina savremenih učenjaka stanovišta je da je taj poslovni model zabranjen, zbog ranije spomenutih razloga.

Ukoliko je usluga ili proizvod koji se nudi putem mrežnog marketinga precijenjen, ne vrijedi novca koji se za njega uzima, to je jasan indikator da je proizvod samo mamac kako bi se profitiralo na principu finansijske piramide. Poslovanje na takav način zabranjeno je, zbog prevare, obmane, bespravnog uzimanja tuđeg imetka, kocke i kamate.

Da bi mrežni marketing bio dozvoljen potrebno je da se ispune sljedeći uvjeti:

- Da proizvod koji se prodaje putem mrežnog marketinga vrijedi cijenu koja se za njega plaća. Time se anulira sumnja postojanja kocke, kamate i prevare.

- Da se kroz marketing proizvoda prezentiraju njegova stvarna svojstva bez preuveličavanja, da se ne daju lažna obećanja i da se ne obmanjuje.

- Da se ne uzima profit od članova iz nižih nivoa kojima se ne čini nikakva usluga, niti s njima postoji izravna veza osim putem učlanjivanja nekog ko je njih učlanio. Dijeliti profit s partnerima iz nižih nivoa ispravno je samo ako se učestvuje s njima u marketingu i prodaji kroz timski rad gdje partneri iz viših nivoa ulažu realan

38 Ibid i Redu Risaletil-ustaz Ibrahim el-Kulsum alad-duktur Sami es-Suvejlim, https://goo.gl/xL7PvP. 
trud i donose korist cijelom timu. Tako se neće bespravno uzimati tuđi imetak.

Mnoge studije, kao i lična iskustva, pokazali su da se iza mrežnog marketinga krije ilegalna finansijska piramida, stoga je osnova da je takav modul poslovanja zabranjen sve dok se ne potvrdi ispunjenje spomenutih uvjeta.

Alternativa mrežnom marketingu je zastupništvo u prodaji ili klasična kupoprodaja, bez kompleksnoga sistema umrežavanja koji se brzo pretvara u ilegalnu finansijsku piramidu. Svevišnji Allah najbolje zna.

\section{LITERATURA}

1. Alvađ Saša, Mrežni marketing na primjeru poduzeća Amway, Studij Poslovna ekonomija, Varaždin.

https://repozitorij.unin.hr/islandora/object/unin\%3A1910/datastream/PD F/view, pristup: 25. 1. 2020.

2. Belfekih Zahir Salim, Et-Tesvik ěs-šebekijj tahtel-midžher, https://www.noor-book.com/كتاب-التسويق-الشبكي-تحت-المجهر-pdf, pristup: 10.

2. 2020 .

3. Debra A. Valentine, Pyramid Schemes, goo.gl/mrTEk3, pristup: 26. 1. 2020.

4. Džasim el-Harun, Šerikatul-ihtijali et-tesvik ěs-šebeki, https://goo.gl/zqpDbx, pristup: 25. 1. 2020.

5. El-'Aude Selman, Bernamidžu vet-tesviku el-heremi avden ala bed', Redu Risaletil-ustaz Ibrahim el-Kulsum alad-duktur Sami es-Suvejlim, El-islamul-jeum https://goo.gl/xL7PvP, pristup: 25. 1. 2020.

6. El-Mevsuatul-fikhijjetul-kuvejtijje, Vizaretul-evkafi veš-šu'unilislamijje, Darus-selasil (1427. h. g.) Kuvajt.

7. Hamza Adnan Mešuka i Ahmed Nuajm Husejn, Et-Tesvik eš-šebekijj min menzurin iktisadijjin islamijj.

https://www.academia.edu/40173438/التسويق_الشبكي_من_منظور_اقتصادي_إسلامي, pristup: 25. 1. 2020.

8. http://laws-lois.justice.gc.ca/fra/lois/C-34, pristup: 26. 1. 2020.

9. http://rajnabanovac.com/2016/10/21/povijest-mlm-a/ pristup: 24. 6 . 2020.

10. https://en.wikipedia.org/wiki/Multi-level_marketing, pristup: 26. 1.2020 .

11. https://goo.gl/78jn8Z, Džeridetul-vefd, pristup: 26. 1. 2020. 
12. https://goo.gl/bEBZdm, Hakikatut-tesvikiš-šebeki.

13. https://goo.gl/O4WAUa, Egyway, 27. 1. 2020.

14. https://hr.wikipedia.org/wiki/Piramida_sreće, pristup: 25. 1. 2020.

15. https://mlmprevara.wordpress.com/2014/02/24/5-velikih-lazi-mreznogmarketinga, pristup: 26. 1. 2020.

16. Muhammed Emin, Gasilul-emvali tahte sitarit-tesvikiš-šebeki, www.masress.com/october/124297, pristup: 27. 1. 2020.

17. Robert FitzPatrick, Ekberu ašereti ekazib an et-tesvik eš-šebeki, https://goo.gl/AiT82W, 26. 1. 2020. 
dr. sci. Hakija Kanurić, assistant professor

University of Bihać

Islamic Pedagogical Faculty

Email: hakijak@botmail.com

\section{NETWORK MARKETING FROM THE ASPECT OF ISLAMIC $L A W$}

\section{Summary}

This paper aims to present network marketing as a model of business, distribution and sale of goods, point out its positives and negatives, practical experiences and legal regulations of some countries towards this business model, and elaborate the opinions of modern Islamic lawyers on network marketing and finally explain its sharia-legal status and explain whether it is compatible with Islamic business norms or not. While studying and analyzing network marketing, the method of theoretical analysis, descriptive-analytical and comparative methods were used. The result of the study shows that network marketing in its usual form, in which membership is conditioned by cash payment or purchase of products, is probibited. In order for network marketing from the aspect of Islamic law to be acceptable, it is necessary that the sale in this way meets the general conditions of purchase and sale in Islamic law, that the product sold in that way is worth the price paid for it, that the product marketing is not deceived and does not take profits from lower-level members to whom no service is rendered.

Keywords: Network marketing, MLM (multi-level marketing), business model, distribution and sale of goods, financial pyramid, Islamic law. 
الدكتور المحاضر هاكيا كانوريتش

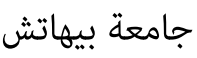
كلية التربية الإسلامية بية E-mail:hakijak@hotmail.comm

\section{التسويق الشبكي في المنظور الإسلامي}

\section{الخلاصة}

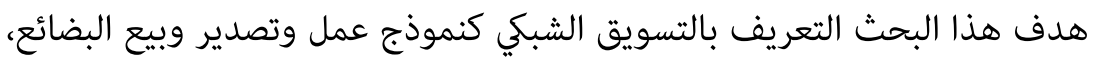

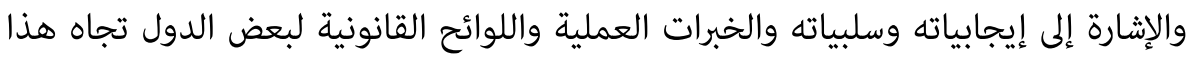

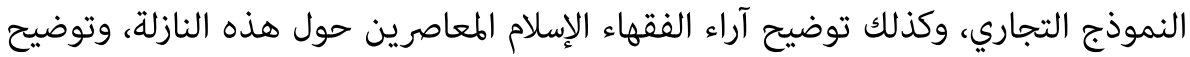
حكمها الشرعي وشرح مدى توافقها مع المعايير الإسلامية لاتعامل التجارئ التهاءي.

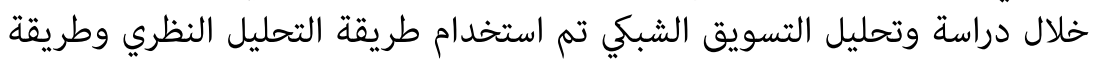
الوصف التحليلي والمقارنة. وتظهر نتيجة البحث أن التسويق الشبكي في شكله المعتاد - حيث تكون العضوية

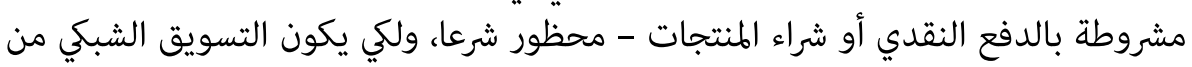

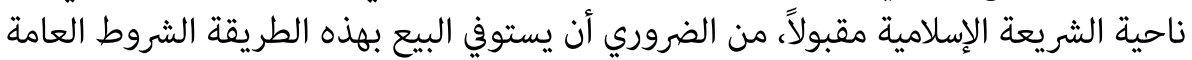

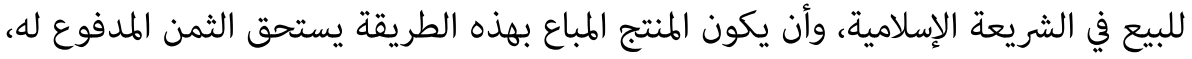

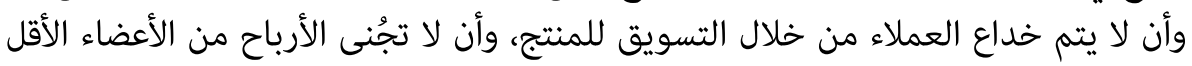

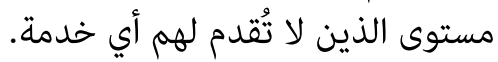

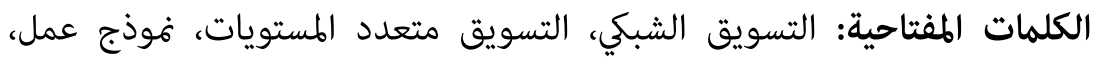
تصدير وبيع البضائع، الهرم المالي، القانون الإسلامي. 